KEY WORDS:

Distribution Coefficient, Solubility, Stochastic Modeling, Variability, Heterogeneity,

RETENTION:

Permanent

\title{
EARLY GUIDANCE FOR ASSIGNING DISTRIBUTION PARAMETERS TO GEOCHEMICAL INPUT TERMS TO STOCHASTIC TRANSPORT MODELS
}

\author{
Daniel I. Kaplan \\ Margaret R. Millings
}

JUNE 30, 2006

Savannah River National Laboratory

Washington Savannah River Company

Savannah River Site

Aiken, SC 29808

Prepared for the U.S. Department of Energy Under

Contract Number DE-AC09-96SR18500 


\section{DISCLAIMER}

This report was prepared for the United States Department of Energy under Contract No. DE-AC09-96SR18500 and is an account of work performed under that contract. Neither the United States Department of Energy, nor WSRC, nor any of their employees makes any warranty, expressed or implied, or assumes any legal liability or responsibility for accuracy, completeness, or usefulness, of any information, apparatus, or product or process disclosed herein or represents that its use will not infringe privately owned rights. Reference herein to any specific commercial product, process, or service by trade name, trademark, name, manufacturer or otherwise does not necessarily constitute or imply endorsement, recommendation, or favoring of same by Washington Savannah River Company or by the United States Government or any agency thereof. The views and opinions of the authors expressed herein do not necessarily state or reflect those of the United States Government or any agency thereof.

Printed in the United States of America

Prepared For

U.S. Department of Energy 
Key Words:

Distribution Coefficient, Solubility, Stochastic Modeling, Variability, Heterogeneity,

Retention:

Permanent

\title{
EARLY GUIDANCE FOR ASSIGNING DISTRIBUTION PARAMETERS TO GEOCHEMICAL INPUT TERMS TO STOCHASTIC TRANSPORT MODELS
}

\author{
Daniel I. Kaplan \\ Margaret R. Millings
}

JUNE 30, 2006

Savannah River National Laboratory

Washington Savannah River Company

Savannah River Site

Aiken, SC 29808

Prepared for the U.S. Department of Energy Under

Contract Number DE-AC09-96SR18500 


\section{REVIEWS AND APPROVALS}

$7 / 20 / 2006$

Daniel I. Kaplan, Co-author, Waste Processing Technology

Date

$7 / 20 / 2006$
Margaret Millings, Co-author, Environmental Science and Biotechnology

Jậè Cook, Peer Revièwer, Waste Processing Technology $\frac{9 / 22 / 06}{\text { Date }}$

B. Thomas Butcher, Level 4 Manager, Waste Processing Technology

$8 / 22 / 06$

Date

William E. Stevens, Authorized Derivative Classifier

William E. Stevens, Authorized Derivative Classifier

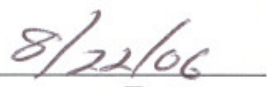

J. C. Griffin, Level 3h Kanager, Waste Processing Technology

Date 


\section{TABLE OF CONTENTS}

LIST OF FIGURES ..................................................................................................................iii

LIST OF TABLES ..............................................................................................................................ii

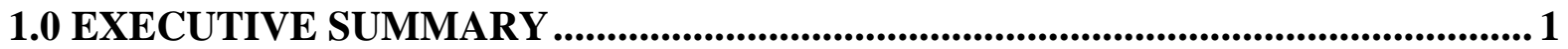

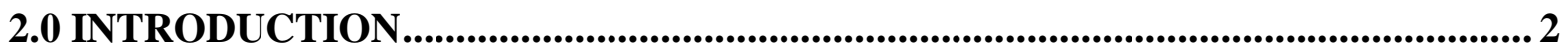

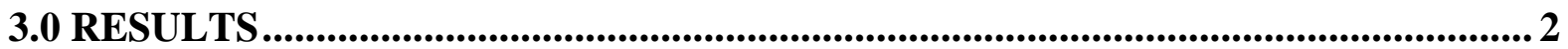

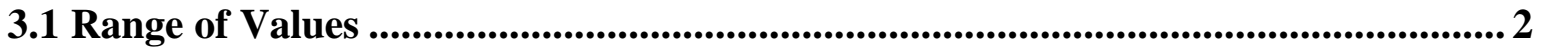

3.2 Distribution of Values...........................................................................................................3

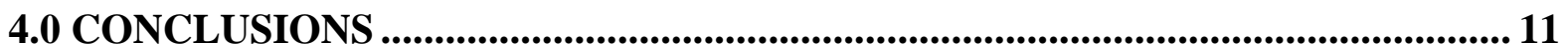

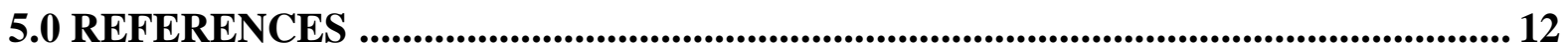

APPENDIX A: Statistics of Kd Distributions.................................................................... 14

APPENDIX B: Range and Distribution of Kd and solubility values Used in E- and Z-

Area Performance Assessment Calculations ......................................................................... 20

\section{LIST OF FIGURES}

Figure 1. Probability Plot (top) and Dot Histogram (bottom) for Cs Kd Values ...................... 7

Figure 2. Probability Plot (top) and Dot Histogram (bottom) for LnCs-Kd ............................ 8

Figure 3. Probability Plot (top) and Dot Histogram (bottom) for Sr Kd Values...................... 9

Figure 4. Probability Plot (top) and Dot Histogram (bottom) for U-Kd Values .................... 10

Figure 5: Dot Histograms for Sr Kd Values for Layer 1 (top) and Layer 2 (bottom) ( $\mathrm{n}=10) 16$

Figure 6: Probability Plots for Sr Kd Values for Layer 1 (top) and Layer 2 (bottom) (n=10)

\section{LIST OF TABLES}

Table 1. Summary statistics of Kd measurements in Hanford sediments................................. 5

Table 2. Kd (mL/g) Values from Borehole 299-E17-21 at Hanford. ................................... 15

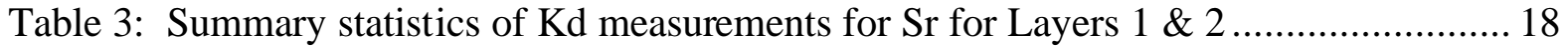

Table 4. Distribution Coefficicients (Kd values, $\mathrm{mL} / \mathrm{g}$ ) ranges and distributions in Sandy and

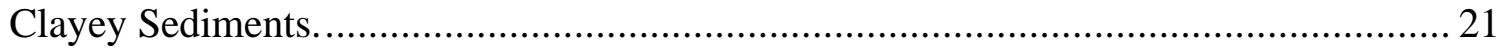

Table 5. Apparent solubility concentration limits (mol/L) for Oxidizing Cementitious Solids

Table 6. Apparent solubility concentration limits (mol/L) for Reducing Cementitious Solids.

Table 7. Distribution coefficients (Kd, $\mathrm{mL} / \mathrm{g}$ ) for Oxidizing Cementitious Solids................ 24

Table 8. Distribution coefficients (Kd, $\mathrm{mL} / \mathrm{g}$ ) for Reducing Cementitious Solids. .............. 25 


\subsection{EXECUTIVE SUMMARY}

Stochastic modeling is being used in the Performance Assessment program to provide a probabilistic estimate of the range of risk that buried waste may pose. The objective of this task was to provide early guidance for stochastic modelers for the selection of the range and distribution (e.g., normal, log-normal) of distribution coefficients $\left(\mathrm{K}_{\mathrm{d}}\right)$ and solubility values $\left(\mathrm{K}_{\mathrm{sp}}\right)$ to be used in modeling subsurface radionuclide transport in E- and Z-Area on the Savannah River Site (SRS). Due to the project's schedule, some modeling had to be started prior to collecting the necessary field and laboratory data needed to fully populate these models. For the interim, the project will rely on literature values and some statistical analyses of literature data as inputs. Based on statistical analyses of some literature sorption tests, the following early guidance was provided:

- Set the range to an order of magnitude for radionuclides with $\mathrm{K}_{\mathrm{d}}$ values $>1000$ $\mathrm{mL} / \mathrm{g}$ and to a factor of two for $\mathrm{K}_{\mathrm{d}}$ values of $<1000 \mathrm{~mL} / \mathrm{g}$. This decision is based on the literature.

- Set the range to an order of magnitude for radionuclides with $\mathrm{K}_{\mathrm{sp}}$ values $<10^{-6} M$ and to a factor of two for $K_{d}$ values of $>10^{-6} M$. This decision is based on the literature.

- The distribution of $\mathrm{K}_{\mathrm{d}}$ values with a mean $>1000 \mathrm{~mL} / \mathrm{g}$ will be log-normally distributed. Those with a $\mathrm{K}_{\mathrm{d}}$ value $<1000 \mathrm{~mL} / \mathrm{g}$ will be assigned a normal distribution. This is based on statistical analysis of non-site-specific data.

Results from on-going site-specific field/laboratory research involving E-Area sediments will supersede this guidance; these results are expected in 2007. 


\subsection{INTRODUCTION}

The objective of this task was to provide early guidance for stochastic modelers who are modeling various aspects of low-level waste disposal in E-Area on the Savannah River Site (SRS). Due to the project's tight schedule, some modeling had to get started prior to collecting the necessary field data needed to fully populate these models. For the interim, we are required to rely on some literature values as inputs. The specific input values that are required are the range and distribution (e.g., normal, log-normal) of distribution coefficients $\left(\mathrm{K}_{\mathrm{d}}\right)$ and solubility values $\left(\mathrm{K}_{\mathrm{sp}}\right)$, both parameters that quantify the extent that radionuclides partition between the aqueous and solid phases in the subsurface environment.

The approach taken in this task was to use the literature to determine the range of values that others have measured. We were unsuccessful in identifying any citations of published work on the distributions of sorption parameters in sediments. So we elected to use multiple $\mathrm{K}_{\mathrm{d}}$ measurement collected from Hanford Site for Sr, Cs, Sr, and U (Kaplan et al. 1998). The statistics and distribution graphs are presented in the Appendix.

\subsection{RESULTS}

\subsection{RANGE OF VALUES}

There has not been any work done to date regarding geochemical parameter input variability as it relates to the SRS performance assessment. However, activity to understand variability and uncertainty associated with these parameters is presently underway. Until this site-specific information is available, the general approach adopted by Wieland and Van Loon (2003) will be used. This approach was one based on professional judgment (Wieland and Van Loon 2003). They calculated an uncertainty factor, $f_{e}$, which was used to provide upper and lower limits for sorption values:

$$
\begin{aligned}
& K d_{\text {max }}=K d \times f_{e} \\
& K d_{\text {min }}=K d / f_{e}
\end{aligned}
$$

The uncertainty range of the sorption values was assumed to be about one order-ofmagnitude for the strongly sorbing radionuclides, with $K d \bullet 1000 \mathrm{~mL} / \mathrm{g}$. The uncertainty accounts for variability associated with environmental conditions (sediment, groundwater conditions, etc.), contaminant concentrations and speciation, and laboratory technique. They assigned an uncertainty factor, $f_{e}$, of 3.3 to $K d$ values $\bullet 1000 \mathrm{~mL} / \mathrm{g}$ and 1.4 to $K d$ values $<1000 \mathrm{~mL} / \mathrm{g}$. The $f_{e}$ of 3.3 yields a range of about one order of magnitude, whereas the $f_{e}$, of 1.4 yields a range of about a factor of 2 .

For example, if the $K d$ value is $1000 \mathrm{~mL} / \mathrm{g}$, then using Equation (1), $K d_{\max }=1000 \times 3.3=$ $3,300 \mathrm{~mL} / \mathrm{g}$, and using Equation (2), $K d_{\min }=1000 / 3.3=303 \mathrm{~mL} / \mathrm{g}$. The range of values would be 3,300 to $303 \mathrm{~mL} / \mathrm{g}$, approximately an order of magnitude difference. Similarly, if $K d$ value is $10 \mathrm{~mL} / \mathrm{g}$, then using equation (1), $K d_{\max }=10 \times 1.4=14 \mathrm{~mL} / \mathrm{g}$, and using 
Equation (2), $K d_{\min }=10 / 1.4=7 \mathrm{~mL} / \mathrm{g}$. The range of values would be 14 to $7 \mathrm{~mL} / \mathrm{g}$, a factorof-two difference. These estimates of variability will provide early guidance. Both Bradbury and Sarott (1995) and Krupka et al. (2004) recommend that the parameters have a normal distribution. Again, this decision appears to be largely based on professional judgment, rather than on a statistical analysis of data. Additional work clearly needs to be conducted to substantiate the assumptions used to describe the variability of the geochemical parameters.

The method of Wieland and Van Loon will be extended to represent the variability of solubility concentration limits $\left(K_{s p}\right) . K_{s p}$ values will be varied in a similar manner as $K d$ :

$$
\begin{aligned}
& K_{s p-\max }=K_{s p} \times f_{e} \\
& K_{s p-\min }=K_{s p} / f_{e}
\end{aligned}
$$

The uncertainty factors, $f_{e}$, will be assigned similar values as those assigned for the $K d$ values in Equation (1) and (2) and the $K_{s p}$ values will be assumed to have a normal distribution. Set the range to an order of magnitude for radionuclides with $K_{s p}$ values $\leq 10^{-6} \mathrm{M}$ and to a factor of two for $K_{s p}$ values of $>10^{-6} \mathrm{M}$.

$K d$ values and $K_{s p}$ values appropriate for SRS are reported in Kaplan (2006).

\subsection{DISTRIBUTION OF VALUES}

For the performance assessments, it is important to understand the distributions of $K d$ values within a specific sorption medium. For example, for describing radionuclide transport through the E-Area surface aquifer, we are interested in the variability associated with the $K d$ values within a specific aquifer, not the variability of all the $K d$ values in the literature or not the variability of $K d$ values in various sediments at the SRS.

There is no site specific data available for calculating the distribution of $K d$ values or solubility constants. Furthermore, there are no reports of the distribution of these parameters in the literature. Consequently, we calculated these based on a data set from the Hanford site (Kaplan et al. 1998). Table A1 in the Appendix provides the laboratory measured $K d$ values for the Hanford boring 299-E17-21. These $K d$ values represent the mean of three replicates for each sample. The reported $K d$ values were collected primarily from two formations. It was statistically determined that the $K d$ values between the two formations were not statistically different for Cs and U. However, the $K d$ values between the two formations were found to be significantly different for Sr. These differences were attributed to differences in $\mathrm{pH}$ and cation exchange between the two formations (Kaplan et al. 1998). Statistical analyses were conducted on data sets combining the $K d$ values from both formations $(n=20)$ for all of the chemical parameters as well as for each formation $(n=10$; Appendix) for $\mathrm{Sr}$.

Table 1 in the Appendix shows summary statistics for the $K d$ values from the Hanford boring. The table includes the (arithmetic) sample mean, a minimum and maximum value of 
the sample population, the variance of the sample population, and the variance of the sample mean. The variance of the sample population is defined by:

$$
s_{X_{i}}^{2}=\frac{1}{n-1} \sum\left(X_{i}-\bar{X}\right)^{2}
$$

where $s_{X_{i}}^{2}$ is the variance of the sample population $\left(s_{X_{i}}\right.$ is the standard deviation of the sample population), $n$ is the number of samples, $X_{i}$ represents each observation and $\bar{X}$ reflects the mean of a randomly sampled population. It reflects the amount of spread in the sample data.

The variance of the sample mean is defined by:

$$
s_{\bar{X}}^{2}=\frac{s_{X_{i}}^{2}}{n} \text { or } s_{\bar{X}}=\frac{s_{X_{i}}}{\sqrt{n}}
$$

where $s_{\bar{X}}$ is the estimated standard deviation of the (arithmetic) sample mean, $s_{X_{i}}$ is the estimated standard deviation of the population, and $n$ is the number of samples (Walpole and Myers 1978). $s_{\bar{X}}$ is the standard error of the mean.

Table 1 also includes skewness and kurtosis. Understanding these two parameters is key for determining if a data set is normally distributed. Skewness is a measure of the symmetry of a distribution about a mean. A skewness value that is far from zero indicates an asymmetric distribution (positive value corresponds to a long right tail and a negative value corresponds to a long left tail). The coefficients of skewness are provided on Table 1. One method of evaluating the skewness value is by comparing it to the standard error of skewness. Values equal to two standard errors of skewness or more can be considered to be significantly skewed. Only Cs has a skewness value (2.1) that is greater than two standard errors of skewness (1.1). The skewness value is less for the transformed Cs dataset (LnCs). The skewness of Cs is discussed further below in the graphical evaluation of the parameter distributions.

A kurtosis value far greater than zero indicates that the distribution has longer tails than a normal distribution whereas a value far less than zero reflects a distribution that is flatter than a normal distribution. The coefficients of kurtosis are provided on Table 1. Values equal to two standard errors of kurtosis or more can be considered to be significant. The kurtosis values for $\mathrm{Cs}$ and $\mathrm{U}$ are greater than two standard errors of kurtosis and indicate that their distributions have longer tails than what would be expected with a normal distribution. Again, the kurtosis value improves for Cs when the dataset is transformed (LnCs).

For this evaluation, summary statistics were performed in Excel and confirmed by using SYSTAT 10.2. Numerical calculations such as skewness and kurtosis can be used as guides for evaluating distributions. However, it should be noted that the values can widely vary for small datasets even for populations that are normally distributed. 
Table 1. Summary statistics of Kd measurements in Hanford sediments.

\begin{tabular}{|c|c|c|c|c|}
\hline \multirow{2}{*}{ Statistic } & \multicolumn{4}{|c|}{$K_{d}(m L / g)^{1}$} \\
\hline & Cs & LnCs & $\mathbf{S r}$ & $\mathbf{U}$ \\
\hline mean & 2055.1 & 7.60 & 14.74 & 0.62 \\
\hline $\min$ & 1373.9 & 7.23 & 12.18 & 0.30 \\
\hline $\max$ & 4068.2 & 8.31 & 16.92 & 0.94 \\
\hline median & 2034.3 & 7.62 & 14.25 & 0.60 \\
\hline count & 20.0 & 20 & 20 & 20 \\
\hline $\begin{array}{c}\text { std deviation of sample mean } \\
\text { (standard error) }\end{array}$ & 133.4 & 0.06 & 0.36 & 0.03 \\
\hline $\begin{array}{c}\text { std deviation of sample } \\
\text { population }\end{array}$ & 596.5 & 0.25 & 1.60 & 0.12 \\
\hline skewness & 2.1 & 1.03 & 0.09 & 0.10 \\
\hline standard error skewness ${ }^{2}$ & 0.55 & 0.55 & 0.55 & 0.55 \\
\hline kurtosis & 6.4 & 2.35 & -1.22 & 3.57 \\
\hline standard error kurtosis ${ }^{2}$ & 1.10 & 1.10 & 1.10 & 1.10 \\
\hline distribution & lognormal & normal & normal & normal \\
\hline
\end{tabular}

${ }^{1}$ Average $\mathrm{pH}$ of samples $=8.75$, with min of 8.5 and maximum of 8.96

${ }^{2}$ Standard error of skewness approximated by $\operatorname{sqrt}(6 / \mathrm{n})$ and standard error of kurtosis approximated by sqrt(24/n), where $n$ equals the count

Graphical methods are also helpful in evaluating whether a distribution is normal. Figures 1 through 6 provide graphs for Cs, the natural log of Cs (LnCs), Sr, and U, were generated using SYSTAT 10.2. For each parameter, the top graph shows a normal probability plot in which the measured values are plotted against the expected values (assuming a normal distribution). On these graphs, the straight line reflects a normal distribution. The left side of the each plot shows the number of standard deviations with " 0 " corresponding to the mean value of the graphed population. The size of the data points show the influence that each point has on a linear fit (or the amount that the correlation would 
change if that particular point was deleted). A small box plot along the top of each graph also shows the distribution of the data. $50 \%$ of the data lie within the box with the box ends representing the $25^{\text {th }}$ and $75^{\text {th }}$ percentiles. The vertical line inside the box reflects the median of the data. Whiskers on the outside of the box show the $10^{\text {th }}$ and $90^{\text {th }}$ percentile. Data outside of the $10^{\text {th }}$ and $90^{\text {th }}$ percentile are plotted as lone points. In addition to the probability plots, a dot histogram with a smoothing line is also provided to show each parameter's distribution.

For Cs, all the data except one, are represented by a small Pearson $r$ Influence dot in the upper Probability Plot in Figure 1. The one data point representing a $K d$ value of $4068 \mathrm{~mL} / \mathrm{g}$, is larger than the rest because it influences the representation of the distribution more than the other data points (i.e., it pulls the data more from a normal to a log-normal distribution).

Given the high skewness value, 2.1 and kurtosis value, 6.4 (Table 1) of this data set, the data was replotted in a log-normal distribution (Figure 2). Note that the skewness and kurtosis in Table 1 decrease and that deviation of the data from the line in the probability plot is smaller in Figure 2. Also the influence of the single large $K d$ value, $\ln (\mathrm{CsKd})=8.31$, was greatly diminished.

Strontium $K d$ value distributions are presented in Figure 3. The data are scattered and the data are normally distributed. As noted above, Kaplan et al. (1998) determined that $\mathrm{Sr} \mathrm{Kd}$ values were significantly different between the two formations. Therefore, separate statistics were conducted on the $K d$ values from each of the two individual formations (Table 3 in Appendix). The statistics became weaker due to the smaller population size $(n=10$ for layer 2 and $n=9$ for layer 1 ), but the result was the same, that $\mathrm{Sr}$ was normally distributed (Appendix).

Uranium was normally distributed and the dot histogram shows a near classical distribution of data with a few data points at the extremes and most points in the middle (Figure 4; Table 1).

The two data sets that had low $K d$ values, $\mathrm{Sr}$ and $\mathrm{U}$, had normal distributions, whereas the only data set with a high $K d$ value, Cs, was log-normally distributed. The cause for this is not known. 
Figure 1. Probability Plot (top) and Dot Histogram (bottom) for Cs Kd Values

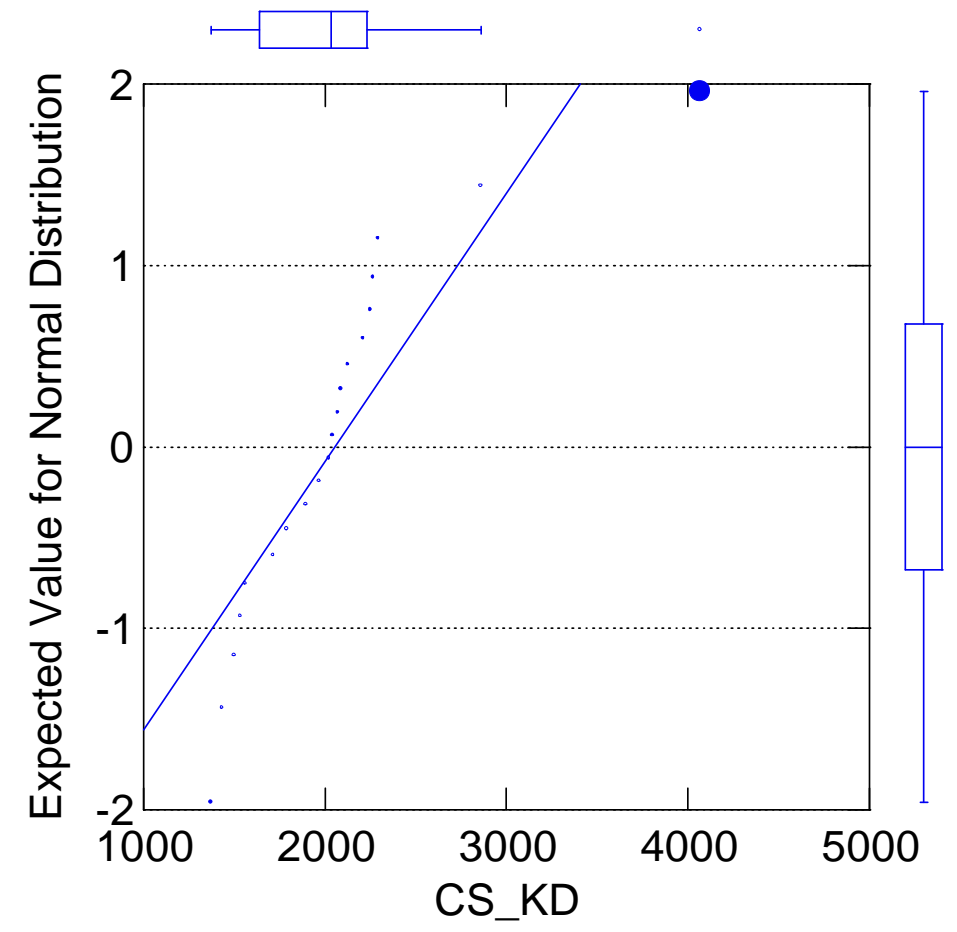

Pearson $r$ Influence

0.10

0.09

0.08

0.07

$\circ 0.06$

$\circ 0.05$

0.04

0.03

0.02

0.01

0.00

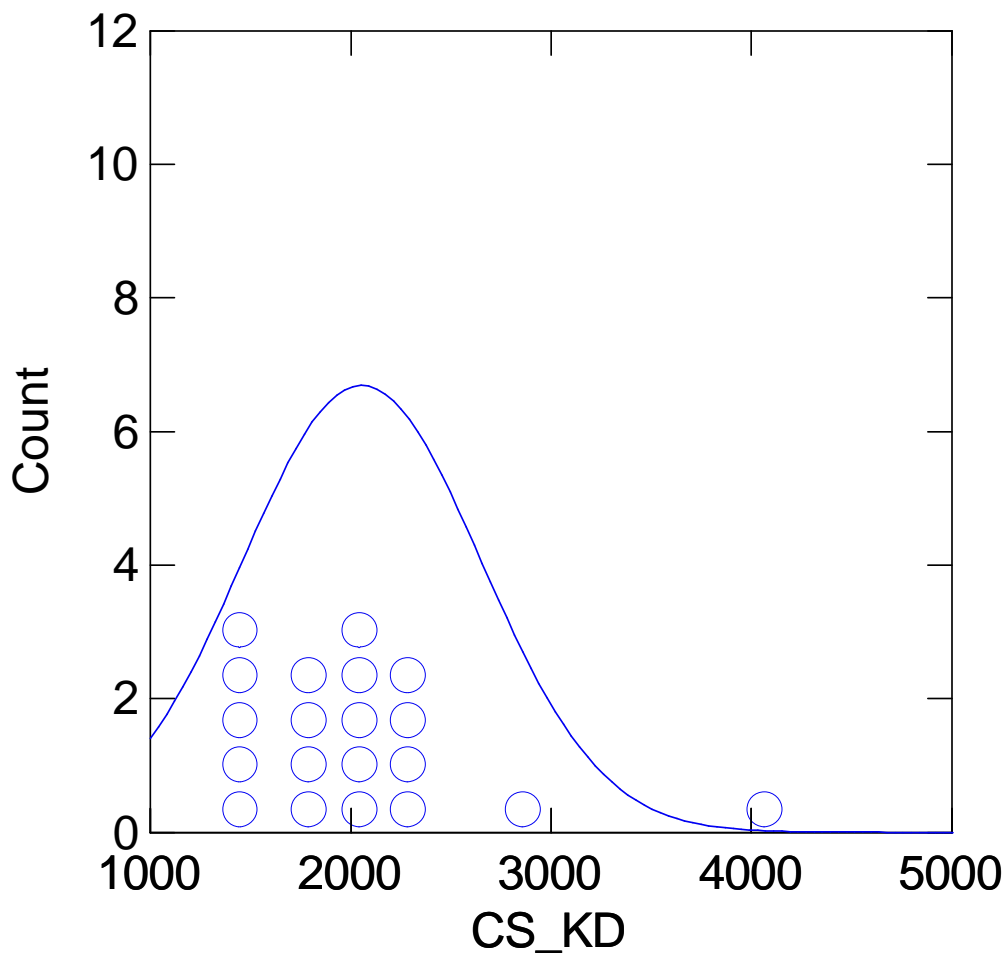

Page 7 of 25 
Figure 2. Probability Plot (top) and Dot Histogram (bottom) for LnCs-Kd
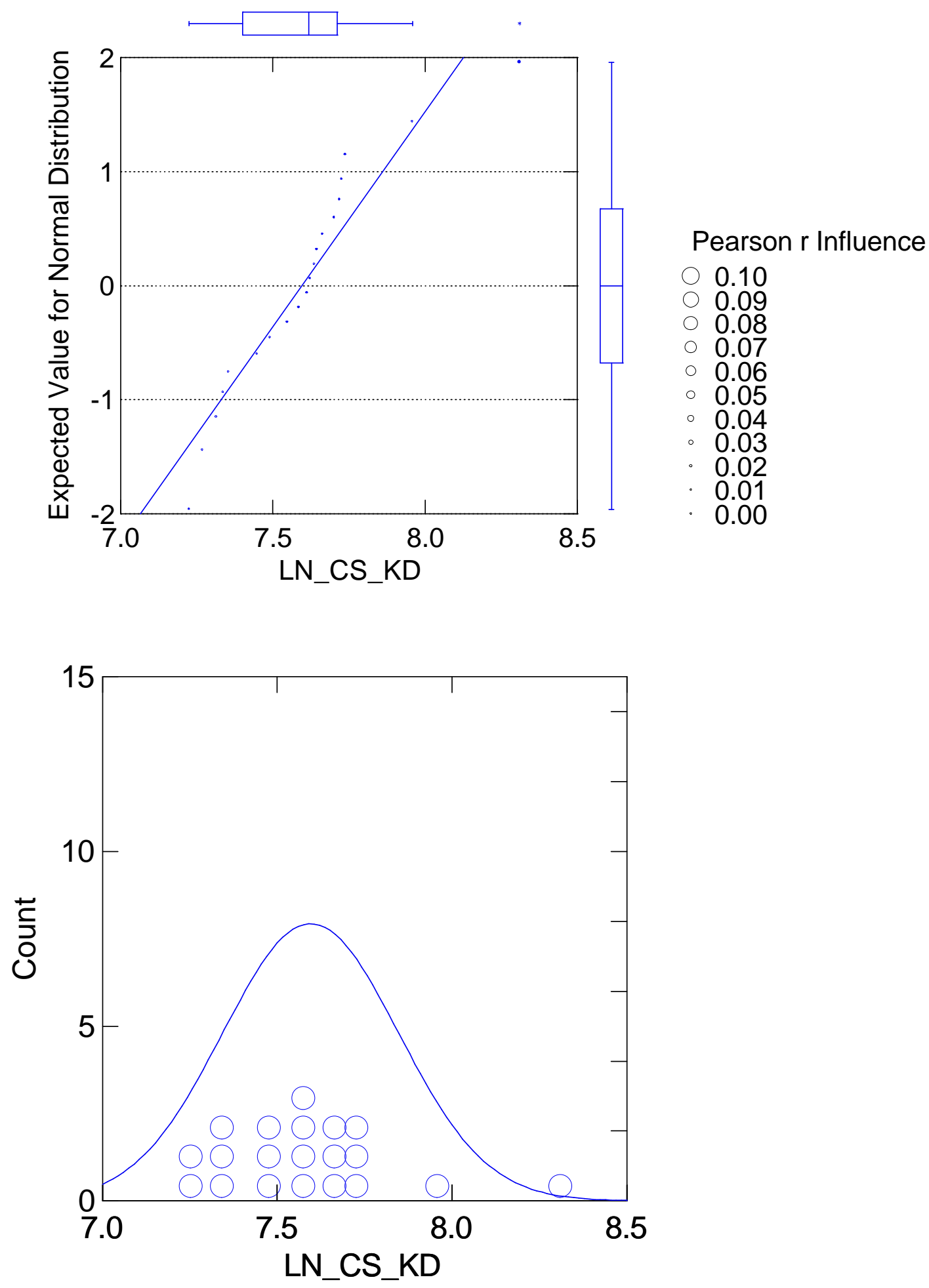

Page 8 of 25 
Figure 3. Probability Plot (top) and Dot Histogram (bottom) for Sr Kd Values
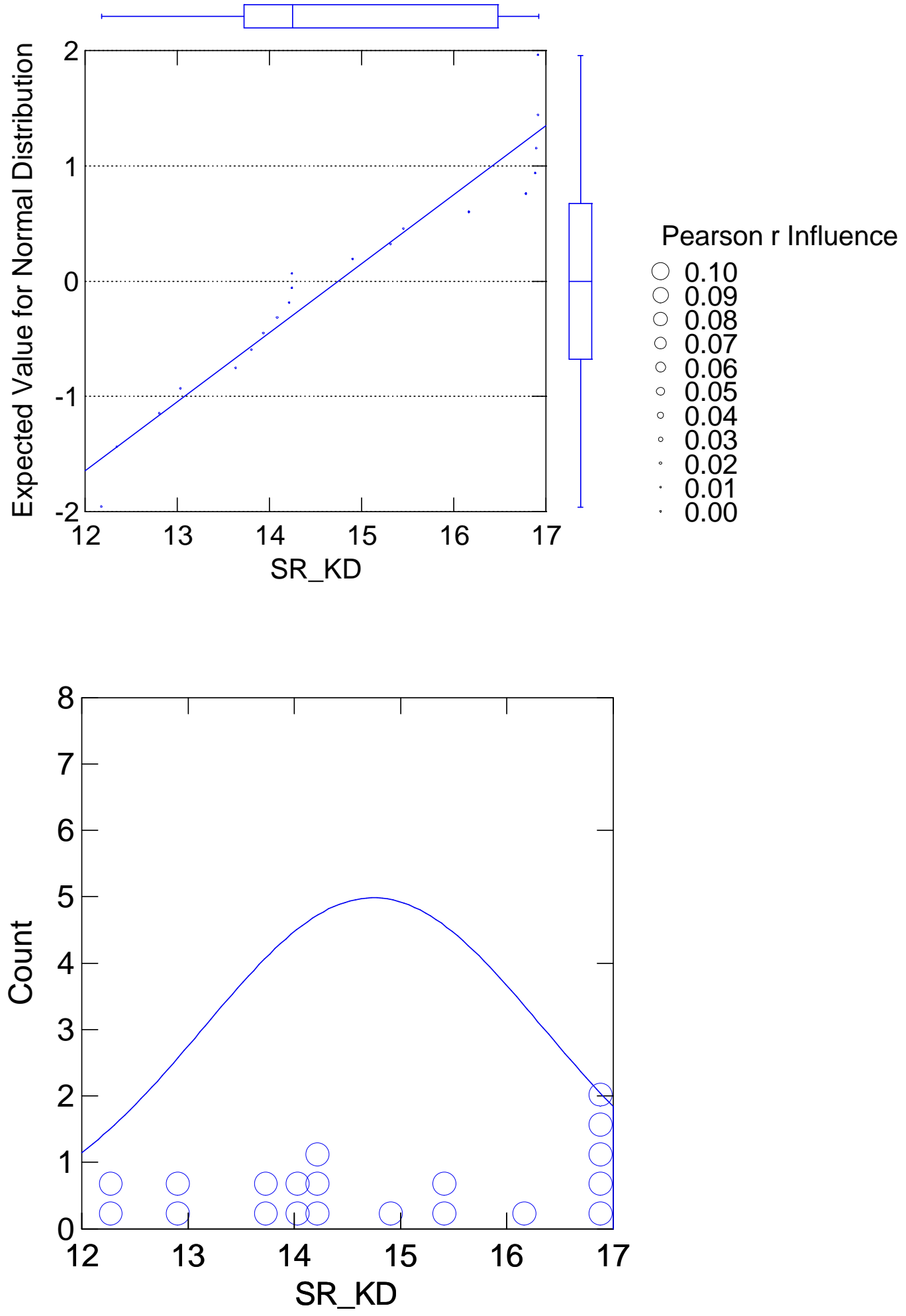

Page 9 of 25 
Figure 4. Probability Plot (top) and Dot Histogram (bottom) for U-Kd Values
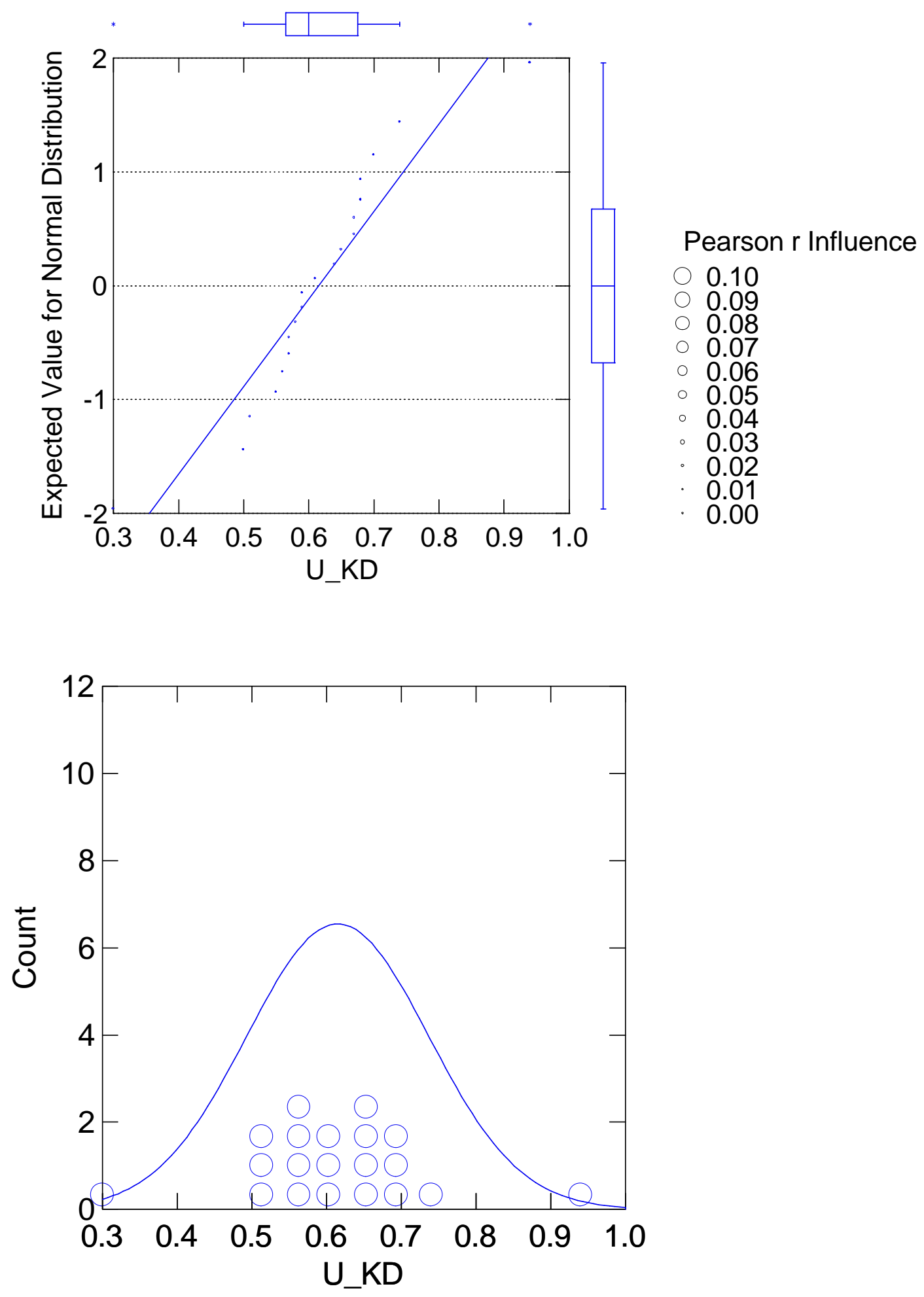

Page 10 of 25 


\subsection{CONCLUSIONS}

Based on statistical analyses of some literature sorption tests, the following early guidance has been provided:

- Set the range to an order of magnitude for radionuclides with $K_{d}$ values $>1000$ $\mathrm{mL} / \mathrm{g}$ and to a factor of two for $\mathrm{K}_{\mathrm{d}}$ values of $<1000 \mathrm{~mL} / \mathrm{g}$. This decision is based on the literature.

- Set the range to an order of magnitude for radionuclides with $\mathrm{K}_{\mathrm{sp}}$ values $<10^{-6} \mathrm{M}$ and to a factor of two for $\mathrm{K}_{\mathrm{d}}$ values of $>10^{-6} \mathrm{M}$. This decision is based on the literature.

- The distribution of $\mathrm{K}_{\mathrm{d}}$ values with a mean $>1000 \mathrm{~mL} / \mathrm{g}$ will be log-normally distributed. Those with a $\mathrm{K}_{\mathrm{d}}$ value $<1000 \mathrm{~mL} / \mathrm{g}$ will be assigned a normal distribution. This is based on our field measurements.

The range and distribution of solubility and $\mathrm{Kd}$ values based on the above guidance and the mean values provided in Kaplan (2006) are provided in Appendix B.

This guidance for stochastic modeling will provide a probabilistic estimate of the range of risk that buried waste may pose. Results from on-going site-specific field/laboratory research involving E-Area sediments will supersede this guidance; these results are expected in 2007. 


\subsection{REFERENCES}

Bradbury, M. H., and F. A. Sarott. 1995. Sorption Databases for the Cementitious Near-field of a L/ILW Repository for Performance Assessment. PSI Bericht Nr. 95-06. Paul Scherrer Institut, Villigen, Switzerland.

Kaplan, D. I. 2006. Geochemical Data Package for Performance Assessment Calculations Related to the Savannah River Site. WSRC-TR-2006-00004, Rev. 0. Washington Savannah River Company, Aiken, SC.

Kaplan, D. I., K. E. Parker, and I. Kutnyakov. 1998. Radionuclide Distribution Coefficients of Sediments Collected from Borehole 299-E17-21. PNNL-11966. Pacific Northwest National Laboratory, Richland, WA.

Krupka, K. M., R. J. Serne, and D. I. Kaplan. 2004. Geochemical Data Package for the 2005 Hanford Integrated Disposal Facility Performance Assessment. PNNL-13037, Rev. 2, Pacific Northwest National Laboratory, Richland, WA.

Walpole, R. E., and R. H. Myers. 1978. Probability and Statistics for Engineers and Scientists, $2^{\text {nd }} e d$. Macmillan Publishing, New York, New York, 580 p.

Wieland, E., and L. R. Van Loon. 2003. Cementitious Near-Field Sorption Data Base for Performance Assessment of an ILW Repository in Opalinus Clay. PSI Bericht 03-06, Paul Scherrer Institut, Villigen, Switzerland. 
WSRC-STI-2006-00019

THIS PAGE INTENTIONALLY LEFT BLANK

Page 13 of 25 


\section{APPENDIX A: STATISTICS OF Kd DISTRIBUTIONS}

Page 14 of 25 
Table 2. Kd (mL/g) Values from Borehole 299-E17-21 at Hanford.

\begin{tabular}{|c|c|c|c|c|c|c|c|c|c|c|}
\hline \multirow{3}{*}{$\frac{\text { Sample ID }}{07 \mathrm{~A}}$} & \multirow{2}{*}{\multicolumn{2}{|c|}{ Depth (m) }} & \multirow{3}{*}{$\begin{array}{c}\mathbf{p H} \\
8.54\end{array}$} & \multirow{3}{*}{$\frac{\text { CEC (meq/100g) }}{5.07}$} & \multicolumn{2}{|l|}{$\mathrm{Cs}$} & \multicolumn{2}{|l|}{$\mathrm{Sr}$} & \multicolumn{2}{|l|}{$\mathbf{U}$} \\
\hline & & & & & \multirow{2}{*}{$\begin{array}{c}\text { value }(\mathbf{m L} / \mathbf{g}) \\
2044.8\end{array}$} & \multirow{2}{*}{$\begin{array}{r}+/- \\
275\end{array}$} & \multirow{2}{*}{\begin{tabular}{c|} 
value $(\mathbf{m L} / \mathbf{g})$ \\
14.09
\end{tabular}} & \multirow{2}{*}{$\begin{array}{r}+/- \\
0.83\end{array}$} & \multirow{2}{*}{\begin{tabular}{|c|} 
value $(\mathbf{m L} / \mathbf{g})$ \\
0.94
\end{tabular}} & \multirow{2}{*}{$\begin{array}{r}+/- \\
0.12\end{array}$} \\
\hline & 14 & 14.6 & & & & & & & & \\
\hline $10 \mathrm{~A}$ & 17.6 & 18.2 & 8.8 & 4.73 & 2090 & 305 & 14.25 & 0.49 & 0.67 & 0.08 \\
\hline $12 \mathrm{~A}$ & 21.2 & 21.6 & 8.77 & 4.6 & 2023.8 & 305 & 13.81 & 0.78 & 0.64 & 0.1 \\
\hline $14 \mathrm{~A}$ & 24.5 & 25.2 & 8.73 & 4.62 & 1969.8 & 39.5 & 13.94 & 0.5 & 0.67 & 0.05 \\
\hline $15 \mathrm{~A}$ & 27.6 & 28.3 & 8.75 & 4.11 & 1502.1 & 80.1 & 13.64 & 0.85 & 0.74 & 0.05 \\
\hline $16 \mathrm{~A}$ & 30.6 & 31.4 & 8.77 & 2.32 & 1535.9 & 270 & 12.81 & 0.33 & 0.57 & 0.04 \\
\hline $17 \mathrm{~A}$ & 33.5 & 34.2 & 8.52 & 4.98 & 2267.2 & 388 & 15.46 & 0.33 & 0.68 & 0.15 \\
\hline $19 \mathrm{~A}$ & 36.9 & 37.6 & 8.5 & 4.72 & 2861.7 & 396 & 14.25 & 0.45 & 0.51 & 0.08 \\
\hline $20 \mathrm{~A}$ & 39.5 & 40.3 & 8.52 & 4.67 & 2251.8 & 292 & 15.32 & 0.37 & 0.65 & 0.08 \\
\hline $21 \mathrm{~A}$ & 43.1 & 43.9 & 8.56 & 4.56 & 2072.5 & 409 & 14.91 & 0.63 & 0.57 & 0.09 \\
\hline $22 \mathrm{~A}$ & 46.3 & 47.1 & 8.94 & 7.33 & 1373.9 & 332 & 12.18 & 0.29 & 0.59 & 0.08 \\
\hline $23 \mathrm{~A}$ & 48.9 & 49.7 & 8.82 & 8.41 & 2295.2 & 280 & 13.04 & 0.95 & 0.58 & 0.05 \\
\hline $24 \mathrm{~A}$ & 55.1 & 55.7 & 8.81 & 9.03 & 2213.3 & 455 & 16.92 & 0.92 & 0.55 & 0.05 \\
\hline $25 \mathrm{~A}$ & 57.8 & 58.5 & 8.89 & 6.63 & 1716.9 & 484 & 12.35 & 0.85 & 0.56 & 0.07 \\
\hline $27 \mathrm{~A}$ & 59.2 & 61.4 & 8.88 & 8.36 & 1563 & 259 & 16.17 & 1.42 & 0.59 & 0.08 \\
\hline $29 \mathrm{~A}$ & 64.3 & 64.4 & 8.84 & 7.77 & 2128.7 & 423 & 14.22 & 0.34 & 0.5 & 0.13 \\
\hline $31 \mathrm{~A}$ & 65.4 & 67.8 & 8.56 & 10.98 & 4068.2 & 259 & 16.9 & 0.11 & 0.3 & 0.12 \\
\hline $32 \mathrm{~A}$ & 69.8 & 70.5 & 8.93 & 8.39 & 1792 & 315 & 16.89 & 1.72 & 0.7 & 0.11 \\
\hline $34 \mathrm{~A}$ & 72 & 72.6 & 8.92 & 6.21 & 1897 & 178 & 16.92 & 1.53 & 0.61 & 0.16 \\
\hline $35 \mathrm{~A}$ & 73 & 73.6 & 8.89 & 6.65 & 1435 & 133 & 16.79 & 2.68 & 0.68 & 0.13 \\
\hline
\end{tabular}

Note: values for each sample represent mean $+/$ - standard deviation based on 3 replicates; only one replicate was used for $\mathrm{pH}$ and cation exchange (CEC) 
Figure 5: Dot Histograms for Sr Kd Values for Layer 1 (top) and Layer 2 (bottom) $(\mathbf{n}=\mathbf{1 0})$

\section{Layer 1}

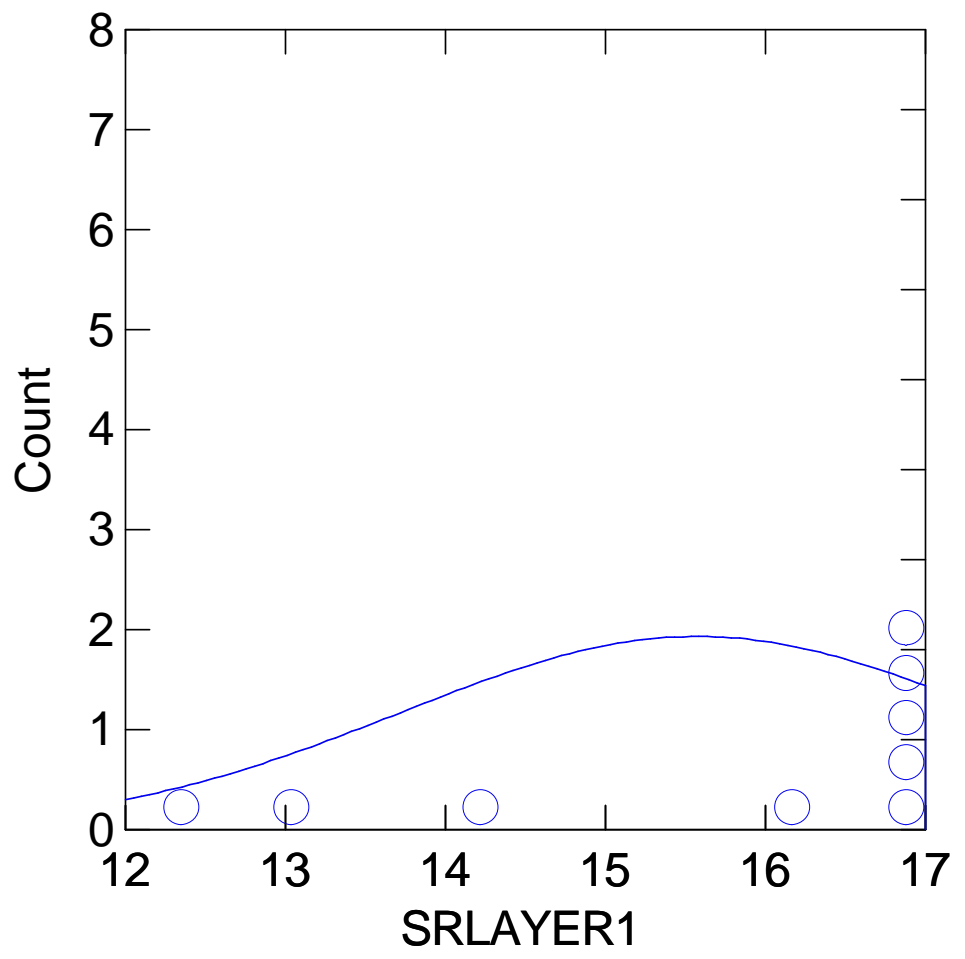

\section{Layer 2}

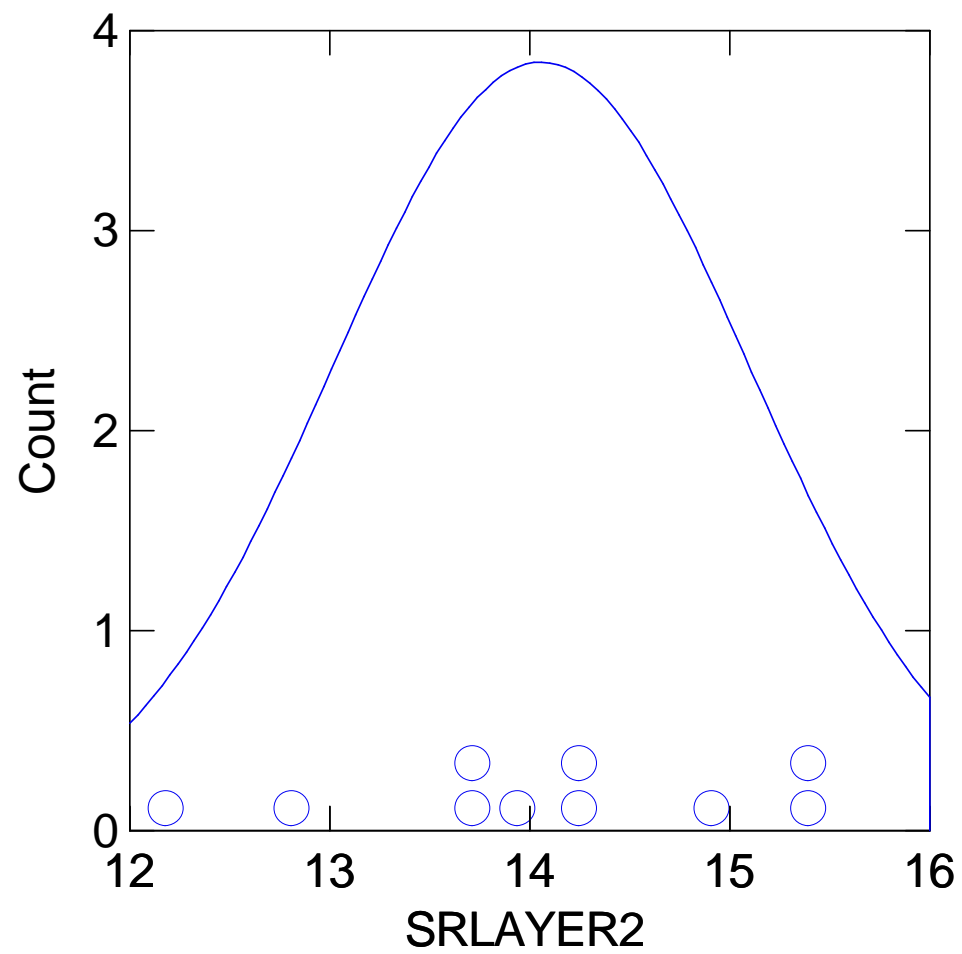

Page 16 of 25 
Figure 6: Probability Plots for Sr Kd Values for Layer 1 (top) and Layer 2 (bottom) $(\mathbf{n}=10)$

\section{Layer 1}

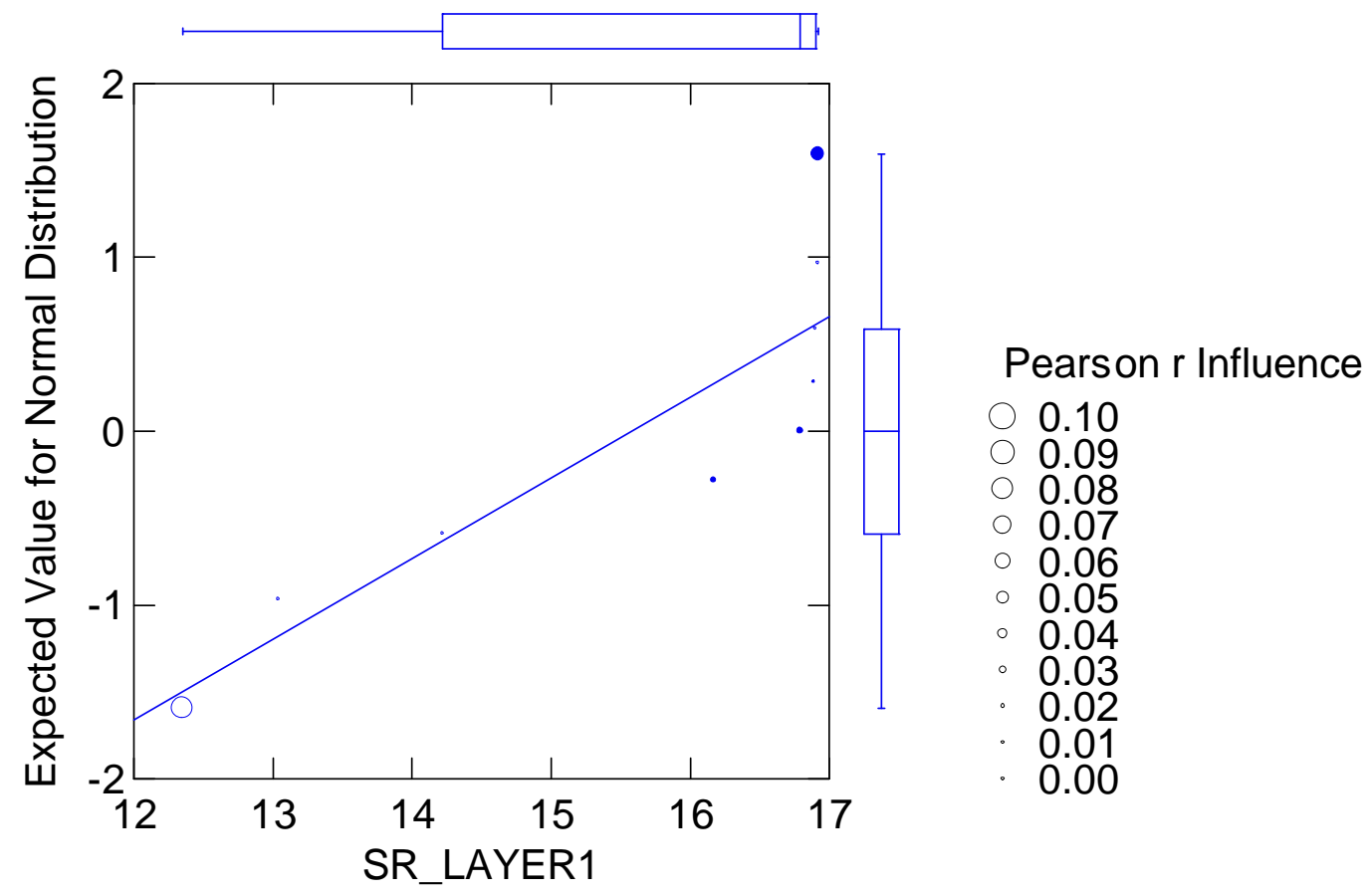

\section{Layer 2}

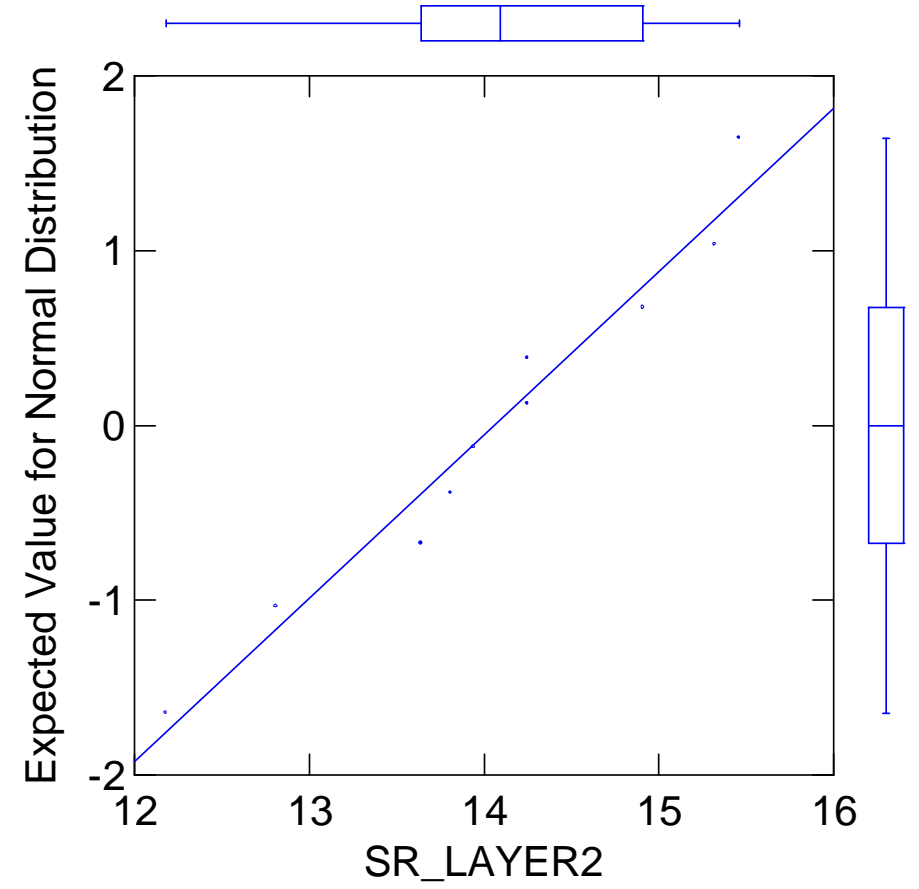

Pearson $r$ Influence

0.10

0.09

0.08

0.07

0.06

0.05

0.04

0.03

- 0.02

- 0.01

0.00 
Table 3: Summary statistics of Kd measurements for Sr for Layers 1 \& 2

\begin{tabular}{|c|c|c|}
\hline \multirow{2}{*}{ Statistic } & \multicolumn{2}{|c|}{$K_{d}(\mathrm{~mL} / g)^{1}$} \\
\hline & Layer $1 \mathrm{Sr}$ & Layer $2 \mathrm{Sr}$ \\
\hline mean & 15.58 & 14.06 \\
\hline $\min$ & 12.35 & 12.18 \\
\hline $\max$ & 16.92 & 15.46 \\
\hline median & 16.79 & 14.10 \\
\hline count & 9 & 10 \\
\hline $\begin{array}{c}\text { std deviation of sample mean } \\
\text { (standard error) }\end{array}$ & 0.62 & 0.33 \\
\hline $\begin{array}{c}\text { std deviation of sample } \\
\text { population }\end{array}$ & 1.86 & 1.04 \\
\hline skewness & -1.03 & -0.40 \\
\hline standard error skewness $^{2}$ & 0.82 & 0.77 \\
\hline kurtosis & -0.78 & -0.23 \\
\hline standard error kurtosis ${ }^{2}$ & 1.63 & 1.55 \\
\hline
\end{tabular}

${ }^{1}$ Average $\mathrm{pH}$ of samples $=8.75$, with min of 8.5 and maximum of 8.96

${ }^{2}$ Standard error of skewness approximated by $\operatorname{sqrt}(6 / \mathrm{n})$ and standard error of kurtosis approximated by $\operatorname{sqrt}(24 / \mathrm{n})$, where $n$ equals the count 


\section{THIS PAGE INTENTIONALLY LEFT BLANK}

Page 19 of 25 

ASSESSMENT CALCULATIONS 
Table 4. Distribution Coefficicients (Kd values, $\mathrm{mL} / \mathrm{g}$ ) ranges and distributions in Sandy and Clayey Sediments.

\begin{tabular}{|c|c|c|c|c|c|c|c|c|c|c|}
\hline \multirow[b]{2}{*}{ Radionuclide } & \multicolumn{5}{|c|}{ Sandy Sediment } & \multicolumn{5}{|c|}{ Clayey Sediment } \\
\hline & Best Kd & Distribution & $\mathrm{fe}$ & $\begin{array}{l}\text { Lower } \\
\text { Limit }\end{array}$ & $\begin{array}{l}\text { Upper } \\
\text { Limit }\end{array}$ & Best Kd & Distribution & $\mathrm{fe}$ & $\begin{array}{l}\text { Lower } \\
\text { Limit }\end{array}$ & $\begin{array}{l}\text { Upper } \\
\text { Limit }\end{array}$ \\
\hline${ }^{3} \mathrm{H}, \mathrm{Kr}, \mathrm{Rn}, \mathrm{Ar}$ & 0 & Normal & 1.4 & 0 & 0 & 0 & Normal & 1.4 & 0 & 0 \\
\hline $\mathrm{Cl}, \mathrm{Nb}$ & 0 & Normal & 1.4 & 0 & 0 & 0 & Normal & 1.4 & 0 & 0 \\
\hline $\begin{array}{l}\mathrm{Ac}, \mathrm{Am}, \mathrm{Bk}, \mathrm{Cf}, \\
\mathrm{Cm}, \mathrm{Eu}, \mathrm{Gd}, \mathrm{Sm}\end{array}$ & 1100 & Log-Normal & 3.3 & 333 & 3630 & 8500 & Log-Normal & 3.3 & 2576 & 28050 \\
\hline Inorganic $\mathrm{C}$ & 0 & Normal & 1.4 & 0 & 0 & 0 & Normal & 1.4 & 0 & 0 \\
\hline $\mathrm{Cs}, \mathrm{Rb}, \mathrm{Fr}$ & 50 & Normal & 1.4 & 36 & 70 & 250 & Normal & 1.4 & 179 & 350 \\
\hline $\mathrm{Co}$ & 7 & Normal & 1.4 & 5 & 10 & 30 & Normal & 1.4 & 21 & 42 \\
\hline I, At & 0 & Normal & 1.4 & 0 & 0 & 0.6 & Normal & 1.4 & 0 & 1 \\
\hline $\mathrm{Ni}$ & 7 & Normal & 1.4 & 5 & 10 & 30 & Normal & 1.4 & 21 & 42 \\
\hline $\mathrm{Np}, \mathrm{Pa}$ & 0.6 & Normal & 1.4 & 0 & 1 & 35 & Normal & 1.4 & 25 & 49 \\
\hline $\mathrm{Pu}(\mathrm{V} / \mathrm{VI})$ & 16 & Normal & 1.4 & 11 & 22 & 5000 & Log-Normal & 3.3 & 1515 & 16500 \\
\hline $\mathrm{Pu}(\mathrm{III} / \mathrm{IV})$ & 300 & Normal & 1.4 & 214 & 420 & 6000 & Log-Normal & 3.3 & 1818 & 19800 \\
\hline $\mathrm{Pu}($ combo $)$ & 270 & Normal & 1.4 & 193 & 378 & 5900 & Log-Normal & 3.3 & 1788 & 19470 \\
\hline $\mathrm{Th}, \mathrm{Zr}$ & 900 & Normal & 1.4 & 643 & 1260 & 2000 & Log-Normal & 3.3 & 606 & 6600 \\
\hline $\mathrm{Pb}, \mathrm{Po}, \mathrm{Sn}$ & 2000 & Log-Normal & 3.3 & 606 & 6600 & 5000 & Log-Normal & 3.3 & 1515 & 16500 \\
\hline $\mathrm{Sr}, \mathrm{Ra}, \mathrm{Ba}$ & 5 & Normal & 1.4 & 4 & 7 & 17 & Normal & 1.4 & 12 & 24 \\
\hline $\mathrm{Se}, \mathrm{Te}$ & 1000 & Log-Normal & 3.3 & 303 & 3300 & 1000 & Log-Normal & 3.3 & 303 & 3300 \\
\hline $\mathrm{Tc}, \operatorname{Re}$ & 0.1 & Normal & 1.4 & 0 & 0 & 0.2 & Normal & 1.4 & 0 & 0 \\
\hline $\mathrm{U}$ & 200 & Normal & 1.4 & 143 & 280 & 300 & Normal & 1.4 & 214 & 420 \\
\hline
\end{tabular}

Best Kds taken from Table 10 in Kaplan (2006).

"fe" = uncertainty factor, defined in equations 1 and 2. 
WSRC-STI-2006-00019

Table 5. Apparent solubility concentration limits (mol/L) for Oxidizing Cementitious Solids

\begin{tabular}{|c|c|c|c|c|c|c|c|c|c|c|c|c|c|c|c|}
\hline \multirow[b]{2}{*}{ Radionuclide } & \multicolumn{5}{|c|}{ Young Cement, 1st Stage } & \multicolumn{5}{|c|}{ Moderately-aged Cement, 2nd Stage } & \multicolumn{5}{|c|}{ Aged Cement, 3rd Stage } \\
\hline & Best & Distribution & fe & Low Kd & Upper Kd & Best & Distribution & fe & $\begin{array}{c}\text { Low } \\
\text { Kd }\end{array}$ & $\begin{array}{c}\text { Upper } \\
\mathrm{Kd} \\
\end{array}$ & Best & Distribution & fe & Low Kd & $\begin{array}{c}\text { Upper } \\
\mathrm{Kd}\end{array}$ \\
\hline $\begin{array}{l}{ }^{3} \mathrm{H}, \mathrm{Cl}, \mathrm{Tc}, \\
\mathrm{Re}, \mathrm{Kr}, \mathrm{Rn}, \\
\mathrm{Ar}, \mathrm{Nb}, \mathrm{Se}, \\
\text { Te, I, At, Cs, } \\
\text { Fr, Rb }\end{array}$ & NA & & & NA & NA & NA & & & NA & NA & NA & & & NA & NA \\
\hline $\begin{array}{l}\mathrm{C} \\
\mathrm{Ac}, \mathrm{Am}, \mathrm{Bk},\end{array}$ & $1.00 \mathrm{E}-06$ & Log-Normal & 3.3 & $3.0 \mathrm{E}-07$ & $3.3 \mathrm{E}-06$ & $1.00 \mathrm{E}-04$ & Normal & 1.4 & 7.1E-05 & $1.4 \mathrm{E}-04$ & $1.00 \mathrm{E}-04$ & Normal & 1.4 & 7.1E-05 & $1.4 \mathrm{E}-04$ \\
\hline $\begin{array}{l}\text { Cf, Cm, Eu, } \\
\text { Gd, Sm }\end{array}$ & $1.00 \mathrm{E}-11$ & Log-Normal & 3.3 & $3.0 \mathrm{E}-12$ & 3.3E-11 & $1.00 \mathrm{E}-08$ & Log-Normal & 3.3 & $3.0 \mathrm{E}-09$ & 3.3E-08 & $1.00 \mathrm{E}-07$ & $\begin{array}{l}\text { Log- } \\
\text { Normal } \\
\text { Log- }\end{array}$ & 3.3 & $3.0 \mathrm{E}-08$ & 3.3E-07 \\
\hline $\mathrm{Co}, \mathrm{Ni}$ & $1.00 \mathrm{E}-07$ & Log-Normal & 3.3 & $3.0 \mathrm{E}-08$ & $3.3 \mathrm{E}-07$ & $1.00 \mathrm{E}-07$ & Log-Normal & 3.3 & $3.0 \mathrm{E}-08$ & 3.3E-07 & $1.00 \mathrm{E}-06$ & $\begin{array}{l}\text { Normal } \\
\text { Log- }\end{array}$ & 3.3 & $3.0 \mathrm{E}-07$ & 3.3E-06 \\
\hline $\mathrm{Np}, \mathrm{Pa}$ & $1.00 \mathrm{E}-08$ & Log-Normal & 3.3 & $3.0 \mathrm{E}-09$ & 3.3E-08 & $1.00 \mathrm{E}-08$ & Log-Normal & 3.3 & 3.0E-09 & 3.3E-08 & $1.00 \mathrm{E}-07$ & $\begin{array}{l}\text { Normal } \\
\text { Log- }\end{array}$ & 3.3 & $3.0 \mathrm{E}-08$ & 3.3E-07 \\
\hline $\mathrm{Ra}$ & $1.00 \mathrm{E}-06$ & Log-Normal & 3.3 & $3.0 \mathrm{E}-07$ & $3.3 \mathrm{E}-06$ & $1.00 \mathrm{E}-06$ & Log-Normal & 3.3 & $3.0 \mathrm{E}-07$ & $3.3 \mathrm{E}-06$ & $1.00 \mathrm{E}-06$ & Normal & 3.3 & $3.0 \mathrm{E}-07$ & 3.3E-06 \\
\hline $\begin{array}{l}\mathrm{Sr}, \mathrm{Ba} \\
\mathrm{Pb}, \mathrm{Po}, \\
\mathrm{Pu}(\mathrm{V} / \mathrm{VI}) \\
\mathrm{Pu}(\mathrm{III} / \mathrm{IV})\end{array}$ & $1.00 \mathrm{E}-05$ & Normal & 1.4 & 7.1E-06 & $1.4 \mathrm{E}-05$ & $1.00 \mathrm{E}-05$ & Normal & 1.4 & 7.1E-06 & $1.4 \mathrm{E}-05$ & NA & & & NA & NA \\
\hline $\begin{array}{l}\mathrm{Pu}(\text { combo) } \\
\mathrm{Th}, \mathrm{Zr}, \mathrm{Sn}\end{array}$ & $1.00 \mathrm{E}-08$ & Log-Normal & 3.3 & 3.0E-09 & 3.3E-08 & $1.00 \mathrm{E}-08$ & Log-Normal & 3.3 & 3.0E-09 & $3.3 \mathrm{E}-08$ & $1.00 \mathrm{E}-07$ & $\begin{array}{l}\text { Log- } \\
\text { Normal } \\
\text { Log- }\end{array}$ & 3.3 & 3.0E-08 & 3.3E-07 \\
\hline $\mathrm{U}(\mathrm{VI})$ & $1.00 \mathrm{E}-07$ & Log-Normal & 3.3 & $3.0 \mathrm{E}-08$ & 3.3E-07 & $1.00 \mathrm{E}-07$ & Log-Normal & 3.3 & $3.0 \mathrm{E}-08$ & $3.3 \mathrm{E}-07$ & $1.00 \mathrm{E}-06$ & Normal & 3.3 & $3.0 \mathrm{E}-07$ & 3.3E-06 \\
\hline
\end{tabular}

Best Kds taken from Table 11 in Kaplan (2006).

"fe" = uncertainty factor, defined in equations 3 and 4. 
Table 6. Apparent solubility concentration limits (mol/L) for Reducing Cementitious Solids.

\begin{tabular}{|c|c|c|c|c|}
\hline \multirow[b]{2}{*}{ Radionuclide } & \multicolumn{2}{|r|}{ Young Cement, 1st Stage } & Moderately-aged Cement, 2nd Stage & Aged Cement, 3rd Stage \\
\hline & Best & Distribution fe Low Kd Upper Kd & Best Kd Distribution fe Low Kd Upper Kd & Best Kd Distribution fe Low Kd Upper Kd \\
\hline
\end{tabular}

${ }^{3} \mathrm{H}, \mathrm{Cl}, \mathrm{Kr}, \mathrm{Rn}, \mathrm{Sr}$,

$\mathrm{Ra}, \mathrm{Zr}, \mathrm{Th}, \mathrm{Nb}$,

$\mathrm{Sn}, \mathrm{I}, \mathrm{Cs}, \mathrm{Ac}, \mathrm{Am}$,

$\mathrm{Cf}, \mathrm{Cm}, \mathrm{Eu}, \mathrm{Po}$,

$\mathrm{Se}, \mathrm{C}, \mathrm{Co}, \mathrm{Ni}, \mathrm{Pb}$,

Bk, Sm, Fr, Gd, See Oxidizing Cementitious Solids

At, Ar, Te, Ba (See Table 5)

Tc (IV), Re(IV) 1.00E-10 Log-Normal 3.3 3.0E-11 3.3E-10

$\mathrm{Np}$ (IV), Pa(IV) 1.00E-06 Log-Normal 3.3 3.0E-07 3.3E-06

1.00E-10 Log-Normal 3.3 3.0E-11 3.3E-10 1.00E-06 Log-Normal 3.3 3.0E-07 3.3E-06 1.00E-10 Log-Normal 3.3 3.0E-11 $3.3 \mathrm{E}-10$ 1.00E-10 Log-Normal 3.3 3.0E-11 3.3E-10

$\mathrm{Pu}$ (combo) 1.00E-10 Log-Normal 3.3 3.0E-11 3.3E-10 $\mathrm{U}$ 1.00E-06 Log-Normal 3.3 3.0E-07 3.3E-06
1.00E-10 Log-Normal 3.3 3.0E-11 3.3E-10 1.00E-05 Normal 1.4 7.1E-06 1.4E-05 1.00E-09 Log-Normal 3.3 3.0E-10 3.3E-09 1.00E-09 Log-Normal 3.3 3.0E-10 3.3E-09 1.00E-07 Log-Normal 3.3 3.0E-08 3.3E-07

Best Kds taken from Table 12 in Kaplan (2006).

"fe" = uncertainty factor, defined in equations 3 and 4. 
Table 7. Distribution coefficients (Kd, mL/g) for Oxidizing Cementitious Solids.

\begin{tabular}{|c|c|c|c|c|c|c|c|c|c|c|c|c|c|c|c|}
\hline \multirow[b]{2}{*}{ Radionuclide } & \multicolumn{5}{|c|}{ Young Cement, 1st Stage } & \multicolumn{5}{|c|}{ Moderately-aged Cement, 2nd Stage } & \multicolumn{5}{|c|}{ Aged Cement, 3rd Stage } \\
\hline & $\begin{array}{l}\text { Best } \\
\text { Kd }\end{array}$ & Distribution & fe & $\begin{array}{l}\text { Low } \\
\text { Kd }\end{array}$ & $\begin{array}{l}\text { Upper } \\
\mathrm{Kd}\end{array}$ & $\begin{array}{l}\text { Best } \\
\mathrm{Kd}\end{array}$ & Distribution & $\mathrm{fe}$ & $\begin{array}{l}\text { Low } \\
\mathrm{Kd}\end{array}$ & $\begin{array}{l}\text { Upper } \\
\mathrm{Kd}\end{array}$ & $\begin{array}{l}\text { Best } \\
\mathrm{Kd}\end{array}$ & Distribution & fe & $\begin{array}{l}\text { Low } \\
\text { Kd }\end{array}$ & $\begin{array}{l}\text { Upper } \\
\text { Kd }\end{array}$ \\
\hline $\begin{array}{l}\mathrm{Tc}(\mathrm{VII}), \mathrm{Re}, \\
\mathrm{Kr}, \mathrm{Rn}, \mathrm{Ar}\end{array}$ & 0 & Normal & 1.4 & 0 & 0 & 0 & Normal & 1.4 & 0 & 0 & 0 & Normal & 1.4 & 0 & 0 \\
\hline $3-\mathrm{H}$ & 0 & Normal & 1.4 & 0 & 0 & 0 & Normal & 1.4 & 0 & 0 & 0 & Normal & 1.4 & 0 & 0 \\
\hline $\mathrm{Cl}$ & 0.8 & Normal & 1.4 & 0.6 & 1.1 & 2 & Normal & 1.4 & 1 & 3 & 0 & Normal & 1.4 & 0 & 0 \\
\hline $\mathrm{I}, \mathrm{At}$ & 8 & Normal & 1.4 & 6 & 11 & 20 & Normal & 1.4 & 14 & 28 & 0 & Normal & 1.4 & 0 & 0 \\
\hline Inorganic C & 20 & Normal & 1.4 & 14 & 28 & 10 & Normal & 1.4 & 7 & 14 & 0 & Normal & 1.4 & 0 & 0 \\
\hline $\begin{array}{l}\mathrm{Ac}, \mathrm{Am}, \mathrm{Bk}, \\
\mathrm{Cf}, \mathrm{Cm}, \mathrm{Eu}, \\
\mathrm{Gd}, \mathrm{Sm}\end{array}$ & 5000 & Log-Normal & 3.3 & 1515 & 16500 & 5000 & $\begin{array}{l}\text { Log- } \\
\text { Normal } \\
\text { Log- }\end{array}$ & 3.3 & 1515 & 16500 & 500 & Normal & 1.4 & 357 & 700 \\
\hline $\mathrm{Co}, \mathrm{Ni}$, & 1000 & Log-Normal & 3.3 & 303 & 3300 & 1000 & Normal & 3.3 & 303 & 3300 & 500 & Normal & 1.4 & 357 & 700 \\
\hline $\mathrm{Ra}, \mathrm{Ba}$ & 100 & Normal & 1.4 & 71 & 140 & 100 & Normal & 1.4 & 71 & 140 & 70 & Normal & 1.4 & 50 & 98 \\
\hline $\mathrm{Sr}$ & 1 & Normal & 1.4 & 1 & 1 & 1 & Normal & 1.4 & 1 & 1 & 0.8 & Normal & 1.4 & 1 & 1 \\
\hline $\mathrm{Sn}$ & 4000 & Log-Normal & 3.3 & 1212 & 13200 & 4000 & Log-Normal & 3.3 & 1212 & 13200 & 2000 & Log-Normal & 3.3 & 606 & 6600 \\
\hline $\mathrm{Cs}, \mathrm{Fr}$ & 2 & Normal & 1.4 & 1 & 3 & 4 & Normal & 1.4 & 3 & 6 & 2 & Normal & 1.4 & 1 & 3 \\
\hline $\mathrm{Nb}$ & 1000 & Normal & 1.4 & 714 & 1400 & 1000 & $\begin{array}{l}\text { Log-Normal } \\
\text { Log- }\end{array}$ & 3.3 & 303 & 3300 & 500 & Normal & 1.4 & 357 & 700 \\
\hline $\mathrm{Np}, \mathrm{Pa}$ & 2000 & Log-Normal & 3.3 & 606 & 6600 & 2000 & Normal & 3.3 & 606 & 6600 & 200 & Normal & 1.4 & 143 & 280 \\
\hline $\mathrm{Se}, \mathrm{Te}$ & 300 & Normal & 1.4 & 214 & 420 & 300 & Normal & 1.4 & 214 & 420 & 150 & Normal & 1.4 & 107 & 210 \\
\hline $\begin{array}{l}\mathrm{Pb}, \mathrm{Po}, \\
\mathrm{Pb}, \mathrm{Po}, \\
\mathrm{Pu}(\mathrm{V} / \mathrm{VI}) \\
\mathrm{Pu}(\mathrm{III} / \mathrm{IV})\end{array}$ & 500 & Normal & 1.4 & 357 & 700 & 500 & Normal & 1.4 & 357 & 700 & 250 & Normal & 1.4 & 179 & 350 \\
\hline $\begin{array}{l}\mathrm{Pu}(\text { combo }), \\
\mathrm{Th}, \mathrm{Zr}\end{array}$ & 5000 & Log-Normal & 3.3 & 1515 & 16500 & 5000 & $\begin{array}{l}\text { Log- } \\
\text { Normal }\end{array}$ & 3.3 & 1515 & 16500 & 500 & Normal & 1.4 & 357 & 700 \\
\hline $\mathrm{U}$ & 1000 & Log-Normal & 3.3 & 303 & 3300 & 1000 & Log-Normal & 3.3 & 303 & 3300 & 70 & Normal & 1.4 & 50 & 98 \\
\hline
\end{tabular}

Best Kds taken from Table 13 in Kaplan (2006).

"fe" = uncertainty factor, defined in equations 1 and 2. 
Table 8. Distribution coefficients (Kd, $\mathrm{mL} / \mathrm{g}$ ) for Reducing Cementitious Solids.

\begin{tabular}{|c|c|c|c|c|c|c|c|c|c|c|c|c|c|c|c|}
\hline \multirow[b]{2}{*}{ Radionuclide } & \multicolumn{5}{|c|}{ Young Cement, 1st Stage } & \multicolumn{5}{|c|}{ Moderately-aged Cement, 2nd Stage } & \multicolumn{5}{|c|}{ Aged Cement, 3rd Stage } \\
\hline & $\begin{array}{c}\text { Best } \\
\mathrm{Kd}\end{array}$ & Distribution & fe & $\begin{array}{c}\text { Low } \\
\mathrm{Kd}\end{array}$ & $\begin{array}{c}\text { Upper } \\
\mathrm{Kd}\end{array}$ & $\begin{array}{c}\text { Best } \\
\mathrm{Kd}\end{array}$ & Distribution & fe & $\begin{array}{c}\text { Low } \\
\mathrm{Kd}\end{array}$ & $\begin{array}{c}\text { Upper } \\
\mathrm{Kd}\end{array}$ & $\begin{array}{c}\text { Best } \\
\mathrm{Kd}\end{array}$ & Distribution & fe & $\begin{array}{c}\text { Low } \\
\mathrm{Kd}\end{array}$ & $\begin{array}{c}\text { Upper } \\
\mathrm{Kd}\end{array}$ \\
\hline $\begin{array}{l}\text { All rads } \\
\text { except the } \\
\text { following }\end{array}$ & Same & values as report & $\mathrm{d}$ in $\mathrm{T}$ & ble7. & & & & & & & & & & & \\
\hline $\mathrm{Tc}, \mathrm{Re}$ & 5000 & Log-Normal & 3.3 & 1515 & 16500 & 5000 & Log-Normal & 3.3 & 1515 & 16500 & 5000 & $\begin{array}{l}\text { Log- } \\
\text { Normal } \\
\text { Log- }\end{array}$ & 3.3 & 1515 & 16500 \\
\hline $\mathrm{U}$ & 5000 & Log-Normal & 3.3 & 1515 & 16500 & 5000 & Log-Normal & 3.3 & 1515 & 16500 & 5000 & Normal & 3.3 & 1515 & 16500 \\
\hline
\end{tabular}




\section{DISTRIBUTION}

\section{Savannah River Site}

B. T. Butcher

773-43A, Rm. 216

L. B. Collard

773-43A, Rm. 207

J. R. Cook

773-43A, Rm. 209

K. P. Crapse

773-43A, Rm. 212

773-42A, Rm. 211

705-3C, Rm. 105

W. T. Goldston

773A, Rm. A-231

J. C. Griffin

773-42A, Rm. 220

R. A. Hiergesell

773-42A, Rm. 251

D. I. Kaplan (3 copies)

773-43A, Rm. 215

M. A. Phifer

773-42A, Rm. 252

W. E. Stevens

773-A, Rm. A-261

R. F. Swingle

773-42A, Rm. 122

G. A. Taylor

773-41A, Rm. 156

E. L. Wilhite

773-43A, Rm. 214

WPT File ( 2 copies)

773-43A, Rm. 213

STI (3 copies)

703-43A 